\title{
Utilizing Authentic Materials on Students' Listening Comprehension: Does it have Any Influence?
}

\author{
Resti Citra Dewi* \\ Postgraduate Program, English Applied Linguistics. State University of Medan, Indonesia
}

CorrespondingAuthor: Resti Citra Dewi, Email - citradewiresti@rocketmail.com

\section{ARTICLE INFO}

Article history

Received: December 17, 2017

Accepted: January 25, 2018

Published: February 28, 2018

Volume: 9 Issue: 1

Advance access: January 2018

Conflicts of interest: None

Funding: None

\begin{abstract}
The purpose of this study was to investigate the influence of using authentic materials on EFL students' in listening comprehension. The participants of this study was the second year students of Junior High School in Indonesia, 2014/2015 academic year. The population of this study consisted of five parallel classes with the total number of the students was 190 students. Purposive sampling technique was used in this study. The participants were divided into two groups, the experimental was 38 students and the control group was 38 students. This study used experimental research. The instrument used in collecting data was multiple choice test. The total items of the test was 20 items. The finding shows that t-test (5.09) was higher than t-table (2.02) with the level of significance 0.05 and the degree of freedom (df) $=36$. It shows that the hypothesis alternative (ha) was accepted. It means that using authentic materials has influence on students' achievement in listening comprehension.
\end{abstract}

Key words:

Listening Comprehension,

Authentic Materials

\section{INTRODUCTION}

Listening is one of receptive skills in English. Listening is not only hearing, but also listening to something carefully. In this case, someone can listen, but may not understand it (Broughton et al., 1978). According to Buck (2001)listening is an active process of comprehending the meaning, and listening is done by applying the knowing to the sound. Therefore, listening considers as an active process because it involves speaker's accent, pronounciation, grammar and vocabulary. It means that before people get abilities to speak, read, and write they must listen first before talking or doing other physical activities and when they are reading and talking, they must listen to get the information and knowledge.

When the researcher did macro teaching found out that there were some students' problems in listening comprehension. The first reason the researcher chose this title because the the students had difficulties in learning listening comprehension. Their scores do not achieve Minimum Passing Grade (MPG). The problem arose because English is still foreign for them, the second reason was because without listening comprehension, oral communication cannot run well. The third reason was because the teachers had difficulties to find the effective materials to increase the students' ability in listening. The teachers often use the conventional way in teaching listening comprehension. Sometimes, they still read the materials when studying about listening, where the students should rewrite what they listened from the teacher. It can make the students feel bored and they are not interested in listening comprehension.

According to Kelly, Kelly, Offner \& Vorland (2002) believe that authentic materials are useful media, which can be used to relate between classroom and the real world. Authentic materials help to give motivation the students learn the language, and they will feel that they are learning the real language (Guariento \& Morely, 2001). Underwood (1989) said that a much more real act of communication is heard by the learners by using authentic materials. The learners are given a real representation speech with hesitation, false starts and mistakes which will help the learner to master with the real life speech when they meet it in other situation or the teaching-learning process. The learners will have the chance to listen to authentic text, which they will hear in different various accents. In this case, the researcher used authentic materials as an effort to achieve maximum learning results. So the researcher was interested in research the effect of using authentic materials on the students' achievement in listening comprehension of the students of Junior High School (SMP Negeri 13 Medan of the academic year of 2014/2015). This research was done to investigate whether there is significant effect of using authentic mate- 
rials in teaching listening comprehension to EFL students' classroom.

\section{REVIEW OF LITERATURE}

\section{Description of Authentic Materials}

Authentic materials is one of the good materials that can be used in teaching listening comprehension classroom. Authentic materials are materials made by native speakers that can be used in teaching and learning process but not purely designed for teaching. This part will explain some of the definitions of the term "authentic materials" generally, in some points of view of the writers:

1. Herrington and Oliver (2000) said that a new pedagogical term, called "authentic learning". This term is related to the students' real life and prepares the students to face and deal with real world situations.

2. According to Herod (2002) authentic learning 'materials and activities' are designed to imitate the real world situations.

3. Jacobson et al (2003) defines authentic materials as printed materials, which are used in classrooms in the same way they would be used in real life.

4. According to Carter \& Nunan (2001) authentic materials are "ordinary texts not produced specifically for langugae teaching purposes."

5. According Martinez (2002:1) authentic materials sometimes called "authentic" or "contextualized", real-life materials are those that a student sees in everyday life but that weren't created for educational purposes. The materials include newspapers, magazines, and Websites, as well as driver's manuals, utility bills, pill bottles, and clothing labels.

Teaching materials are a very important part of teaching and learning process, especially in teaching a foreign language. Nowadays, teaching material is easy to find wherever, and can be used for whoever. One of teaching matrials can be found in the internet. The internet is rich source for authentic materials. Genhard (1996) divided authentic materials into three following categories:

1. Authentic listening materials, such as cartoons, radio news, songs, etc.

2. Authentic visual materials, such as street signs, post cards,magazines and newspapers pictures, etc.

3. Authentic printed materials, such as newspapers,sports reports, train tickets, restaurant menus, etc.

\section{The Use of Authentic Materials in the Classroom}

Empirical studies have shown the significant effects of using authentic texts by language learners in teaching learning process. Beside that, some other researchers have done research that using authentic materials has significant influence in improving reading comprehension by presenting expressions and new words to students (Bacon \& Finneman, 1990; Berardo, 2006). Moreover, Harmer (1991) said that using authentic materials can improve students' listening and reading skills. Allen et al. (1998), as cited in Baird, 2004) mentions that in the objective of language learning authentic texts develop the learner's comprehending in their writing proficiency. While according to Omagio Hadley (1993) and Rogers and Medley (1988), if students can improve a functional proficiency in the language and can use the language communicatively in the real world, they will feel the language of the real world in the classroom. Furhtermore, the learners should get the opportunities to practice by adapting or listening the real language as authentic texts and materials in their classroom situations to master the foreign language. The result of other studies (Bacon \& Finnermann's, 1990; Otte, 2006; Thanajaro, 2000) have claimed that increasing students' motivation and self-satisfaction can use authentic aural texts as the source of learning. This is an advantage of using authentic materials in teaching foreign language and also will increase learners' motivation. Mc Neil (1994) and Kilickaya (2004) said that the use of authentic texts is a technique which can be used in language learning to increase students' motivation because the students feel that they are learning the real language.

\section{Description of Listening Comprehension}

Brown (1994) gives definition about listening comprehension that it is not only the process of sending and receiving sounds, but also as the interactive and conscious process to send and transmit the message to the brain which will influence in the process of communication. Beside that, Bulletin (1952) defines listening is one of the crucial abilities that makes all users of the language to get information, instruction and comprehension in general. Furthermore, Byrne (1984) also defines listening as the basic mechanism through which the main rules of the language are acquired. Listening is an active process of making sense of what we hear. Language skills are often categorized as receptive and productive. Speaking and writing as productive skill that requires other receiver to understand incoming information (input). Listening is receptive skill, we can listen to and understand things at higher level then we can procedure. So that is why people sometimes think of it as a passive skill.

\section{Hypothesis}

The hypothesis of this research as follows:

Ha: Authentic Materials have a significant effect on students' listening comprehension.

Ho: Authentic Materials do not have a significant effect on students' listening comprehension.

\section{METHODOLOGY}

\section{Research Design}

This research uses the experimental quantitative research. The experimental research is a study of two different groups, experimental that consisted of 38 students and control group 
consisted of 38 students. Authentic materials were used in the experimental group, while non-authentic materials were used in the control group. The table 1 below is the design of this research.

\section{Subjects and Sample}

The population of this study was taken from the second year students of Junior High School (SMPN 13 Medan) of 2014/2015 academic year in Indonesia, which consisted of five parallel classes. In each class consisted of 38 students with the total number of all the students were 190 students. This study applied purposive sampling technique because this subject is considered too big to conduct. In this case, there were 76 students as the sample of this research. Therefore, the researcher has divided into two groups, 38 students for experimental group and 38 students for control group.

\section{Instrument and Materials}

In this research multiple-choice test was used as the instrument in collecting the data. The media that were used as the source of the data were songs as authentic materials which were taken from some singers. The test consisted of 20 items, each item of the test consisted of 3 options, namely $\mathrm{a}, \mathrm{b}$, and c. To validate the instrument of this research, the validity and reliability of the test were established. These two factors should be fulfilled by a test before they were used to derive valid data in a research. Validity is a measurement that show in the high level of capability or validity measurement. There are 38 respondents of the validity of the test at the second grade students of Junior High School of 2014/2015 academic year. To examine the validity of the test, the researcher used correlation product moment from significant;

The other thing was reliability is the consistency and dependability of measure obtained from the test. A test can be said as valid if the test could be reliable, consistence or stable and productive. This mean progressively reliable of the test has conditioned, so progressive certainly researcher can be said that in result of the test has same result when will be done retest.

\section{Technique of Collecting Data}

The data collection was analyzed using SPSS and t-test was computed to determine the groups equivalence. Firstly, pretest was conducted to find out the students' achievement in listening comprehension before having treatment. Secondly, in teaching listening comprehension different treatment was conducted to the experimental group and the control group. Thirdly, post-test was given to both groups, the experimental and the control group after having the treatment. The final test in the research, especially in measuring the treatment, whether it is significant or not, it is applied to know the effect of teaching listening in both classes. It means that before and after giving the treatment is to find out the differences scores between the experimental and the control group.

\section{Technique of Analyzing Data}

In this research, descriptive quantitative technique was applied to analyze the data, and the steps are scoring the students' answer, listing the score into tables for the experimental group scores and the control group scores, and calculating the total score post-test in experimental group and control group.

\section{RESULT AND DISCUSSION}

This study investigated the influence of using Authentic Materials on EFL students' listening comprehension. The scores obtained from the students' listening comprehension pre- and post-tests were compared. In order to answer the research question, descriptive analysis and paired samples t-tests were used to investigate significant differences in the results of the post-test compared with those of the pre-test for both of groups. Table 2 below is the report of control group.

Table 2 shows that the scores of the students in the control group improved significantly in listening comprehension scores $[\mathrm{t}=11.12, \mathrm{p}=0.000]$. There are significant differences between the students' achievement in the post-test scores at the level of $\mathrm{p}<.05$.

For the experimental group, table 3 below reports the paired samples t-test results for listening comprehension scores.

Table 3 reveals that the experimental group affect significantly in listening comprehension $[\mathrm{t}=4.45, \mathrm{p}=0.000]$ at the level of $\mathrm{p}<.05$ in favor of the post-test results. The results of both groups showed that there were significant effect on students' listening comprehension. Based on the data of this

Table 1: Research design

\begin{tabular}{llll}
\hline Group & Pre-Test & Treatment & Post test \\
\hline Experimental & $\sqrt{ }$ & Using authentic materials & $\sqrt{ }$ \\
Control & $\sqrt{ }$ & Using non-authentic materials & $\sqrt{ }$ \\
\hline
\end{tabular}

Table 2: Paired t-test results for control group (differences between pre- and post-test)

\begin{tabular}{lllccccc}
\hline Group & Variable & Test & No. & Mean & Standard deviation & t value & Sig.(2-tailed) \\
\hline \multirow{2}{*}{ Control } & Listening comprehension & Pre & 38 & 57,89 & 8,75 & 11,12 & $0,000^{* *}$ \\
& & Post & 38 & 70 & 8,78 & & \\
\hline
\end{tabular}

**significant at 0.05 level 
Table 3: Paired t-test results for experimental group (differences between pre- and post- test)

\begin{tabular}{lllccccc}
\hline Group & Variable & Test & No. & Mean & Standard deviation & t value & Sig.(2-tailed) \\
\hline \multirow{2}{*}{ Experimental } & Listening comprehension & Pre & 38 & 59,87 & 10,03 & 4,45 & $0,000^{* *}$ \\
& & Post & 38 & 78,95 & 8,79 & & \\
\hline
\end{tabular}

**significant at 0.05 level

Table 4: The Result of the Post-Test of Experimental and Control Group

\begin{tabular}{lcccccc}
\hline Test & N & Mean & Standard deviation & T & Df & Sig.(2-tailed) \\
\hline Post-Test experimental & 38 & 78,95 & 8,79 & 5,09 & 36 & $0,000^{* *}$ \\
Post-Test control & 38 & 70 & 8,78 & & & \\
\hline
\end{tabular}

**significant at 0.05 level

research, table 4 is the result of post-test of experimental and control group.

The result of the test in table 4, showed whether the authentic materials had influence on the students' listening comprehension. The value of the t_c compared by the t_t, $(5.09>2.02)$. it meant that $\mathrm{H}_{\mathrm{a}}$ was accepted and $\mathrm{H}_{0}$ was rejected. So, it can be concluded that, using authentic materials have influence on students' listening comprehension.

After doing data analysis, the researcher found that that there was a significant effect of using authentic materials on students' listening, it was shown be the t_c (5.09) was higher than the $\mathrm{t} t \mathrm{t}(2.02)$ at $\mathrm{df}$ and $\alpha=0.05$ or $(\overline{5} .09>2.02)$. So, the null hypothesis was rejected and the alternative hypothesis was accepted. It meant that there was a significant effect of listening comprehension by using authentic materials.

\section{CONCLUSION AND SUGGESTION}

After analyzing the data, the result showed that the students who were taught by using authentic materials got better achievement than those taught by using non-authentic materials, and it was proved by the result of post-test both of groups. The highest score of post-test in experimental group was 95 and the lowest score was 65 , while the highest score of post-test in control group was 85 and the lowest score was 55. And there was a significant effect of using Authentic Materials on the students' achievement in listening comprehension, which was proven by the result of the test. $(\mathrm{t}+\mathrm{c}>\mathrm{t} \mathrm{t})$ from significant; at $\mathrm{df}=36$ and $\alpha=5 \%$ or $5.09>2.02$.

Related to the conclusion previously, suggestions are put forward as follows:

1. The English teacher can apply authentic materials in teaching listening comprehension in the classroom because based on the researcher's finding; it was found that there is a significance effect of authentic materials on the students' achievement in listening comprehension.

2. English teacher is advised the use of authentic materials in teaching listening comprehension to students because it can help them in getting better understanding in listening comprehension.

3. It is suggested that the students to practice authentic materials by themselves to encourage their confidence and to improve their achievement in learning listening comprehension.

\section{REFERENCES}

Allen, J., \& Widdowson, H. G. (1979). Teaching the communicative use of English. In C. Brumfit \& K. Johnson (Eds.), The communicative approach to language teaching (pp. 147-157). Oxford: Oxford University Press.

Bacon, S., \& Finneman, M. (1990). A study of attitudes, motives, and strategies of university foreign language students and their disposition to authentic oral and written input. Modern Language Journal, 74(4), 459-73. http:// dx.doi.org/10.1111/j.1540-4781.1990.tb05338.x

Berardo, S. (2006). The use of authentic materials in the teaching of reading. The Reading Matrix, 6(2),60-69.

Broughton, G., Brumfit, C., Flevell, R., Hill, P., \& Pincas, A. (1978). Teaching English as a foreign language. London: Routledge.

Brown, D. (1994). Teaching by Principles. Englewood cliffs. Prentice Halls. USA. Cambridge: Cambridge University Press.

Buck, G. (2001). “Assessing Listening”. Cambridge: Cambridge University Press.

Bulletin. C. (1952). The teaching of listening. In Arif Saricoban Hacettepe University (Beytepe-Ankara, Turkey). The Internet TESL Journal, 5 (12).

Byrnes, H. (1984). The role of listening comprehension: A theoretical base. Foreign Language Annals, 17, 317-329.

Carter, R., \& Nunan, D.(Eds.), (2001). The Cambridge guide to teaching English to speakers of other languages. Cambridge University Press.

Genhard, J., G. (1996). Teaching English as a foreign language: A teacher self-development and methodology. Ann arbor: the university of Michigan press.

Guariento, W. \& J. Morely (2001) Text and task authenticity in the EFL classroom. ELT Journal, 55 (4), 347-353.

Hadley, A. (2001). Teaching language in context ( $3^{\text {rd }}$ ed.). Boston: Thomson Heinle.

Harmer, J. (2007). The practice of English language teaching ( $4^{\text {th }}$ ed.). Harlow, UK: Pearson Education.

Herod, L. (2002). Adult learning from theory to practice. Heinle and Heinle Publishers. Heinemann.

Jacobson, E., Degener, S., \& Purcell-Gates, V., (2003). Creating authentic materials and activities for the adult lit- 
eracy classroom: A handbook for practitioners. USA: NCSALL.

Herrington, J., \& Oliver, R. (2000). An instructional design framework for authentic Hyland, K. 2003. Second Language Writing. Cambridge: Cambridge University Press.

Kelly, C., Kelly L., Offiner, M., and Vorland, B. (2002). Effective ways to use authentic materials with ESL/EFL students. The Internet TESL Journal, (8)11. Available at: http//iteslj.org/Techniques/Kelly-Authentic.html.

Kilickaya, F. (2004). Authentic materials and cultural content in EFL classrooms. The Internet TESL Journal,10(7).

Martinez, S. G. (2002). Authentic materials: An overview.
Free resources for teachers and students of English, Karen's Linguistics Issues, 1-7.

McNeill, A. (1994, April). What makes authentic materials different? The case of English language materials for educational television. Papers presented at the Annual International Language in Education Conference, Hong Kong.

Rogers, C., \& Medley, F. (1988). Language with a purpose: Using authentic materials in the foreign language classroom. Foreign Language Annals, 21, 467-478. http:// dx.doi.org/10.1111/j.1944-9720.1988.tb01098.x

Underwood, M. (1989). Teaching Listening. London: Longman. 